\title{
Pengaruh Blended Learning Terhadap Peningkatan Literasi Matematika Siswa
}

\author{
Indah aritonang ${ }^{1}$, Islamiani Safitri ${ }^{2}$ \\ ${ }^{1,2}$ Program studi pendidikan matematika FKIP Universitas Labuhanbatu \\ Jl. Sisingamangaraja, Labuhanbatu, Sumatera Utara (21415) Indonesia \\ indaharitonang10@gmail.com
}

\begin{abstract}
In 2020 the government issued regulation No.9 of 2020 concerning Guidelines for Large-Scale Social Restrictions (PSBB), causing the teaching and learning process to be hampered as a result of decreasing students' mathematical literacy. Based on the results of observations at the Private Madrasah Aliyah Pondok Pesantren Irsyadul Islamiyah Tanjung Medan, it shows that students' mathematical literacy is still very low. Based on this, it is necessary to have a learning method that can improve students' mathematical literacy skills and still follow the protocols implemented by the government (PSBB). This study aims to improve students' mathematical literacy during this pandemic by using a blended learning model. The research method used is quantitative with quasi-experimental (quasi-experimental). The population in this study were students of class XIB which amounted to the experimental class and class XIA as the control class. The instruments and data collection techniques used were essay-shaped tests and observation techniques to find out how students understood the lesson by applying the blended learning method. Based on the results of the research and data processing that have been discussed, it can be concluded that the application of the Blended learning method has an impact on the quality of student learning in terms of mathematical literacy during the corona virus pandemic. In addition, it is known that the influence of the Blended learning method on students' mathematical literacy is $30 \%$, while conventional learning methods only have an effect of $2.44 \%$ and it can be concluded that there are differences in student learning outcomes on the Blended Learning and conventional learning methods with a difference of $24.76 \%$.
\end{abstract}

Keywords: Mathematical Literacy, Blended Learning, CAR

\begin{abstract}
Abstrak
Pada tahun 2020 pemerintah mengeluarkan peraturan No.9 Tahun 2020 tentang Pedoman Pembatasan Sosial Berskala Besar (PSBB), menyebabkan proses belajar mengajar terhambat akibatnya literasi matematika siswa menurun. Berdasarkan hasil observasi pada MAs Pondok Pesantren Irsyadul Islamiyah Tanjung Medan menunjukkan bahwa literasi matematika siswa masih sangat rendah. Berdasarkan hal tersebut perlu adanya metode pembelajaran yang memungkinkan dapat meningkatkan kemampuan literasi matematika siswa dan tetap mengikuti protokol yang di terapkan oleh pemerintah (PSBB). Penelitian ini bertujuan untuk melihat pengaruh Blended Learning terhadap peningkatan literasi matematika siswa. Metode penelitian yang digunakan adalah kuantitatif dengan eksperimen semu (quasi eksperimen). Populasi pada penelitian adalah siswa kelas XIB yang berjumlah kelas eksperimen dan kelas XIA sebagai kelas kontrol. Instrument dan teknik pengumpulan data yang digunakan adalah tes berbentuk essay dan teknik observasi untuk mengetahui cara siswa memahami pelajaran dengan penerapan metode blended learning. Berdasarkan hasil penelitian dan pengolahan data yang telah dibahas dapat disimpulkan bahwa penerapan metode pembelajaran Blended learning memiliki dampak terhadap kualitas belajar siswa ditinjau dari literasi matematika pada masa pandemik virus korona. Selain itu diketahui bahwa besar pengaruh metode Blended learning terhadap literasi matematika siswa sebesar 30\%, sedangkan metode belajar konvensional hanya berpengaruh sebesar $2.44 \%$ serta dapat disimpulkan ada perbedaan hasil belajar siswa terhadap metode belajar Blended Learning dan konvensional dengan perbedaan sebesar $24.76 \%$.
\end{abstract}

Kata kunci: Literasi Matematika, Blended Learning, PTK

Copyright (c) 2021 Indah aritonang, Islamiani Safitri

$\triangle$ Corresponding author: Indah aritonang

Email Address: ndaharitonang10@gmail.com_(Jl. Sisingamangaraja, Labuhanbatu, Sumatera Utara (21415) Indonesia)

Received 18 Maret 2021, Accepted 24 Maret 2021, Published 26 Maret 2021

\section{PENDAHULUAN}

Sejak Desember 2019 negara mengalami pandemi secara global, yakni mewabahnya virus baru yang disebut Coronavirus Deseae. Covid-19 merupakan penyakit jenis baru yang belum pernah diidentifikasi sebelumnya pada manusia. Pada 2 maret 2020, terdapat dua kasus pertama kali 
dikonfirmasi di Indonesia, selanjutnya menjadi 790 kasus pada minggu ketiga (Wulandari et al., 2020). Pemerintah melalui kementerian kesehatan menerbitkan peraturan menteri kesehatan No.9 Tahun 2020 tentang Pedoman Pembatasan Sosial Berskala Besar (PSBB)(Hairi, 2020), yang mana pembatasan tersebut meliputi meliburkan sekolah-sekolah, kampus-kampus, tempat kerja, kegiatan keagamaan, pembatasan ditempat/fasilitas umum, pembatasan sosial budaya, dan pembatasan lainnya yang menimbulkan keramaian guna untuk memutus rantai penularan covid-19 (Irfanudin et al., 2020).

Sejak PSBB diberlakukan, pemerintah menginstruksikan kebijakan baru yaitu melakukan kegiatan belajar mengajar di rumah secara daring. Hal ini dilakukan agar siswa tidak berhenti mendapatkan pendidikan sekaligus untuk membantu pemerintah dalam memutus mata rantai penularan covid-19 di Indonesia. Menurut Skiner dalam (Ratnawati, 2016) menyatakan bahwa pendidikan merupakan segala usaha yang dirancang untuk mempengaruhi manusia yang awal mulanya tidak tahu menjadi memiliki pengetahuan melalui pembelajaran sehingga dapat merubah pola pikirnya. Tujuan pendidikan adalah indikator keberhasilan pelaksanaan pendidikan.

Matematika ialah salah satu bidang ilmu pengetahuan eksak yang lebih mementingkan pemahaman siswa dari pada hapalan. Tujuan pembelajaran matematika yang ditetapkan oleh Dapartemen Pendidikan Nasional (2006)(Taunu \& Iriani, 2019) sejalan dengan NCTM (2000:67) bahwa terdapat lima kompetensi dalam pembelajaran matematika yaitu pemecahan masalah matematis (mathematical problem solving), komunikasi matematis (mathematical communication), penalaran matematis (mathematical reasoning), koneksi matematis (mathematical connection), dan representasi matematis (mathematical connection)(Wibowo, 2019). Gabungan kelima kompetensi tersebut perlu dimiliki siswa agar dapat mempergunakan ilmu matematika dalam kehidupan sehari-hari. Kemampuan yang mencakup kelima kompetensi tersebut adalah kemampuan literasi matematika (Saleh et al., 2014).

Literasi matematika dapat diartikan sebagai kemampuan seseorang untuk dapat merumuskan, menerapkan serta menafsirkan matematika ke dalam berbagai konteks, yang melibatkan penalaran dan penggunaan konsep, prosuder, fakta, dan alat matematika untuk mendeskripsikan, menjelaskan, dan mengaitkannya dalam kehidupan sehari-hari(Taunu \& Iriani, 2019). Kemampuan literasi matematika berkaitan dengan bagaimana individu dapat mengapliksikan suatu pengetahuan dalam maslah dunia nyata(real word) sehari-hari, sehingga manfaatnya dapat dirasakan secara langsung (Indrawati, 2020). Maka dapat dikatakan, bahwa literasi matematika dapat mempermudah siswa untuk mengetahui lebih jauh peranan matematika di kehidupan sehari-hari.

Akan tetapi dari hasil observasi yang telah dilakukan di Madrasah Aliyah Swasta Pondok Pesantren Irsyadul Islamiyah Tanjung Medan menunjukkan bahwa literasi matematika siswa masih sangat rendah. Data yang diperoleh dari hasil observasi ialah: (1) rendahnya pemahaman siswa terhadap pelajaran matematika (98\% dari 56 siswa), (2) siswa sulit untuk menafsirkan, merumuskan serta menerapkan matematika didalam berbagai konteks dalam kehidupan sehari-hari (90\% dari 56 siswa), (3) rendahnya penalaran matematika siswa (95\% dari 56 siswa), (4) adanya ketidakseimbangan antara pembelajaran keagaaman dengan pembelajaran umum, (5) sekolah hanya memfasilitasi buku panduan untuk guru saja, 
sehingga siswa tidak memiliki buku pegangan di rumah.oleh karena itu, perlu dilakukan upaya khusus untuk meningkatkan literasi siswa.

Salah satu upaya yang dapat dilakukan untuk meningkatkan literasi matematika siswa adalah dengan menggunakan model pembelajaran blended learning. Blended learning merupakan kombinasi pembelajaran tradisional dan lingkungan pembelajaran elektronik. Blended learning menggabungkan aspek pembelajaran berbasis web/internet, streaming video, komunikasi audio synchronous dan asynchronous dengan pembelajaran tradisional "tatap muka"(Rizkiyah, 2013). Model pembelajaran blended learning terdiri atas 3 komponen yaitu online learning, pembelajaran tatap muka, dan belajar mandiri(Wahyuni, 2019). Kelebihan dari blended learning yang diungkapkan oleh kusairi dalam (Siliwangi \& Penelitian, 2020), yaitu:

1. Peserta didik dapat lebih leluasa untuk mempelajari materi pelajaran secara mandiri dengan memanfaatkan materi-materi yang tersedia secara online.

2. Peserta didik dapat berkomunikasi/berdiskusi dengan pengajar atau peserta didik lain yang tidak harus dilakukan saat di kelas (tatap muka).

3. Kegiatan pembelajaran yang dilakukan peserta didik di luar jam tatap muka dapat dikelola dan dikontrol dengan baik oleh pengajar.

4. Pengajar dapat menambahkan materi pengayaan melalui fasilitas internet

5. Pengajar dapat meminta peserta didik membaca materi atau mengerjakan tes yang dilakukan sebelum pembelajarn.

6. Pengajar dapat menyelenggarakan kuis, memberikan balikan, dan memanfaatkan hasil tes dengan efektif

7. Peserta didik dapat saling berbagi file dengan peserta didik lainnya.

Selain usaha untuk memutus tali penularan Covid-19 penerapan model pembelajaran blended learning juga mampu menjadikan siswa lebih aktif dan mandiri dalam proses belajar mengajar.

Berdasarkan yang telah dipaparkan diatas penelitian ini bertujuan untuk mengatasi rendahnya literasi matematika siswa dengan menggunakan model pembelajaran blended learning untuk meningkatkan literasi matematika siswa di Madrasah Aliyah Swasta Pondok Pesantrean Irsyadul Islamiyah Tanjung Medan ditengah-tengah mewabahnya Corona Virus yang menyebabkan siswa tidak dapat melakukan kegiatan belajar secara langsung didalam lingkungan sekolah. Dengan penerapan model pembelajaran blended learning ini diharapkan bisa meningkatkan literasi matematika siswa dalam merumuskan, menafsirkan serta menerapkan matematika didalam berbagai konteks terutama dalam kehidupan sehari-hari (Hidayat et al., 2020).

\section{METODE}

Metode penelitian yang digunakan dalam penelitian ini adalah metode kuantitatif dengan penelitian eksperimen semu (quasi eksperimen). Metode quasi eksperimen adalah suatu bentuk eksperimen yang ciri utama validitasnya tidak dilakukan secara random, melainkan kelompok atau kelas 
yang sudah ada (Ningsih et al., 2017), dimana pada tahap awal setiap kelompok diberikan tes yang sama, kemudian kelas eksperimen diterapkan metode Blended learning. Menggunakan bentuk nonequivalent control group desaign pada desain ini hampir sama dengan pretest-posttest control group design. Berikut tabel design penelitian dari non qeuivalent control group design:

Tabel 1. Non qeuivalent control group design

\begin{tabular}{|l|l|l|}
\hline $\mathrm{O} 1$ & $\mathrm{X}$ & $\mathrm{O} 2$ \\
\hline $\mathrm{O} 3$ & & $\mathrm{O} 4$ \\
\hline
\end{tabular}

Populasi pada penelitian ini ialah seluruh siswa/siswi Madrasah Aliyah Swasta Pondok Pesantren Irsyadul Islamiah kelas XI yang berjumlah 90 siswa. Jika data di ambil dari populasi secara keseluruhan, maka membutuhkan dana serta waktu yang cukup banyak. Solusi agar data yang didapat bisa mewakili data yang ada pada populasi, maka perlu diambil sampel yang mewakili dari populasi. Sampel yang digunakan pada penelitian ini ialah siswa kelas XIB yang berjumlah 34 siswa sebagai kelas eksperimen dan kelas XIA yang berjumlah 34 siswa sebagai kelas kontrol. Teknik sampling yang digunakan ialah probability sampling dengan menggunakan cluster sampling (area sampling)(Sharma, 2017).

Instrumen dan teknik pengumpulan data yang digunakan pada penelitian ini adalah tes berbentuk essay untuk mengukur literasi matematika siswa dan pemahaman konsep siswa, dan observasi digunakan untuk mengetahui cara siswa memahami pelajaran dengan penerapan metode blended learning(sutisna, 2020). Teknik analisis data yang digunakan adalah deskriptif kuantitatif yaitu dengan cara menganalisis data dengan statistik deskriptif seperti Analisis Deskriptif, Uji Normalitas, Uji homogenitas, Uji independent sample $t$ test terhadap hasil essay pre-test dan post-test kemudian disajikan dalam bentuk table, grafik (Isnawati et al., 2020).

\section{HASIL DAN DISKUSI}

Penelitian ini bertujuan untuk melihat pengaruh Blended learning terhadap peningkatan literasi matematika siswa. Untuk menganalisis hasil keberhasilan dari penerapan Blended Learning dalam meningkatkan literasi matematika siswa dapat dilihat dari perubahan hasil belajar siswa dalam menjawab soal matematika, tingkat pemahaman konsep, dan cara memahami pelajaran. Berikut adalah uraian analisis dari penerapan Blended Learning dalam meningkatkan literasi matematika siswa.

\section{Analisis Data Tes}

Untuk menganalisis data dilakukan Pre-Test dan Post-Test terhadap kelas eksperimen dan kelas control (Alan \& Afriansyah, 2017). Pre-Test dan Post-Test yang diberikan kepada siswa berupa tes essay yang berfungsi untuk melihat literasi matematika siswa dan pemahamn konsep siswa dengan materi uji yang disesuaikan dengan tingkatan pendidikan siswa. Pengolahan data hasil Pre-Test dan Post-Test dilakukan dengan menggunakan MS.Excel dan SPSS(Ariskasari \& Pratiwi, 2019). Pre-Test diberikan kepada siswa sebelum penerapan Blended Learning dan Post-Test diberikan kepada siswa 
setelah penerapan Blended Learning. Hasil Pre-Test dan Post-Test yang diperoleh adalah sebagai berikut:

\section{Analisis Deskriptif}

Analisis ini bertujuan untuk memaparkan dan menggambarkan data penelitian berupa jumlah data, nilai minimal, nilai maksimal, nilai rata-rata (Alan \& Afriansyah, 2017). Berikut adalah hasil statistik deskriptif:

Tabel 2. Descriptive Statistics

\begin{tabular}{|c|c|c|c|c|c|}
\hline & N & Minimum & Maximum & Mean & Std. Deviation \\
\hline Pre-Test Eksperimen & 34 & 45 & 77 & 64.41 & 8.454 \\
Post-Test Eksperimen & 34 & 79 & 100 & 90.41 & 6.783 \\
Pre-Test Kontrol & 34 & 51 & 75 & 63.21 & 7.348 \\
Post-Test Konrol & 34 & 51 & 79 & 65.56 & 7.835 \\
Valid N (listwise) & 34 & & & & \\
\hline
\end{tabular}

Berikut adalah bagan untuk hasil tes siswa:

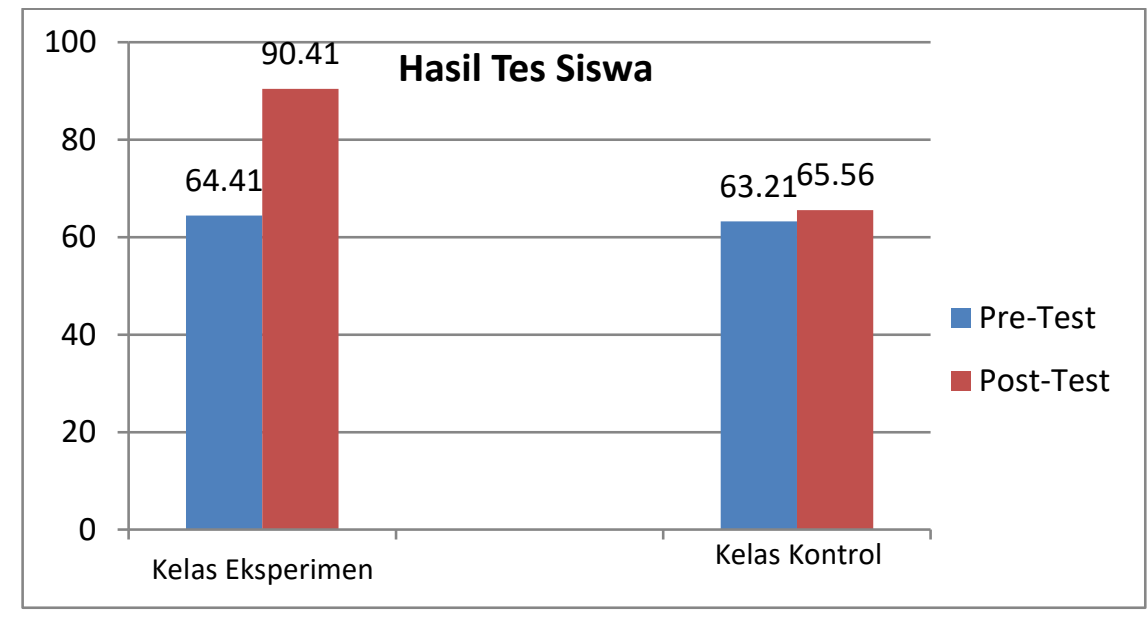

Gambar 1. Bagan Descriptive Statistics

Berdasarkan tabel dan gambar diatas diketahui nilai pre-test siswa untuk kelas eksperimen sebesar 64.41 dan kelas kontrol sebesar 63.21 serta nilai post-test untuk kelas eksperimen sebesar 90.41 dan kelas kontrol sebesar 65.56.

\section{Uji Normalitas}

Pengujian uji normalitas data dilakukan untuk mengetahui apakah data berdistribusi normal yang merupakan syarat mutlak untuk pengujian analisis parametrik (paired sample $t$ test dan independent sample t test) (Farisi et al., 2017). Berikut hasi uji normalitas data:

Tabel 3. Tests of Normality

\begin{tabular}{|c|c|c|c|c|c|c|c|}
\hline & \multirow[b]{2}{*}{ Kelas } & \multicolumn{3}{|c|}{ Kolmogorov-Smirnov $^{\mathrm{a}}$} & \multicolumn{3}{|c|}{ Shapiro-Wilk } \\
\hline & & Statistic & $\mathrm{df}$ & Sig. & $\begin{array}{c}\text { Statisti } \\
\text { c }\end{array}$ & df & Sig. \\
\hline \multirow{2}{*}{$\begin{array}{l}\text { Hasil } \\
\text { Siswa }\end{array}$} & Belajar Pre-Test Eksperimen & .120 & 34 & $200^{*}$ & .957 & 34 & .204 \\
\hline & $\begin{array}{l}\text { Post-Test } \\
\text { Eksperimen }\end{array}$ & .104 & 34 & $200^{*}$ & .937 & 34 & .051 \\
\hline
\end{tabular}




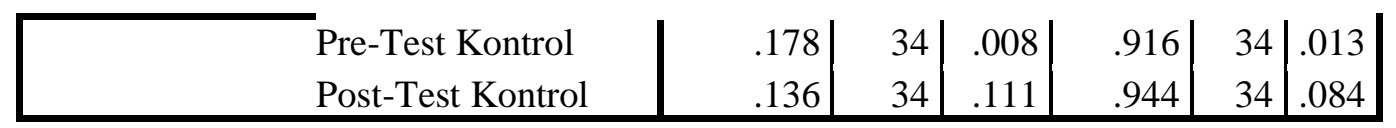

Berdasarkan hasil uji nomalitas dapat diketahui bahwa data berdistriusi normal dilihat dari nilai Sig $>$ 0.05, baik pada uji Kolmogoro-Sminorv (Nahdi, 2018) maupun Shapiro-Wilk (Suyana et al., 2019). Dengan demikian maka dapat dilakukan uji paired sample t test terhadap data.

\section{Uji Homogenitas}

Analisis ini bertujuan untuk melihat varian data Pre-Test dan Post-Test terhadap kelas eksperimen dan kelas kontrol adalah sama atau HOMOGEN (Wiliawanto et al., 2019). Berikut hasil analisis data:

Tabel 6. Test of Homogeneity of Variance

\begin{tabular}{|c|c|c|c|c|c|}
\hline & & $\begin{array}{l}\text { Levene } \\
\text { Statistic }\end{array}$ & df1 & df 2 & Sig. \\
\hline \multicolumn{2}{|c|}{ Hasil Belajar Based on Mean } & 1.592 & 1 & 66 & .211 \\
\hline \multirow[t]{3}{*}{ Siswa } & Based on Median & 1.150 & 1 & 66 & .287 \\
\hline & $\begin{array}{l}\text { Based on Median and with } \\
\text { adjusted df }\end{array}$ & 1.150 & 1 & 63.387 & .288 \\
\hline & Based on trimmed mean & 1.570 & 1 & 66 & .215 \\
\hline
\end{tabular}

Berdasarkan hasil tersebut diketahui Pre-Test dan Post-Test terhadap kelas eksperimen dan kelas kontrol adalah sama atau HOMOGEN dilihat dari nilai Sig. Based on Mean sebesar $0.211>0.05$, dengan demikian salah satu syarat (tidak mutlak) dari Uji independent sample t test terpenuhi (Farisi et al., 2017).

\section{Uji independent sample t test (Jika data Normal)}

Analisis ini bertujuan untuk melihat perbedaan hasil belajar siswa terhadap metode belajar (Pamungkas et al., 2017) Blended Learning dan konvensional. Berikut hasil analisis data:

Tabel 7. Independent Samples Test

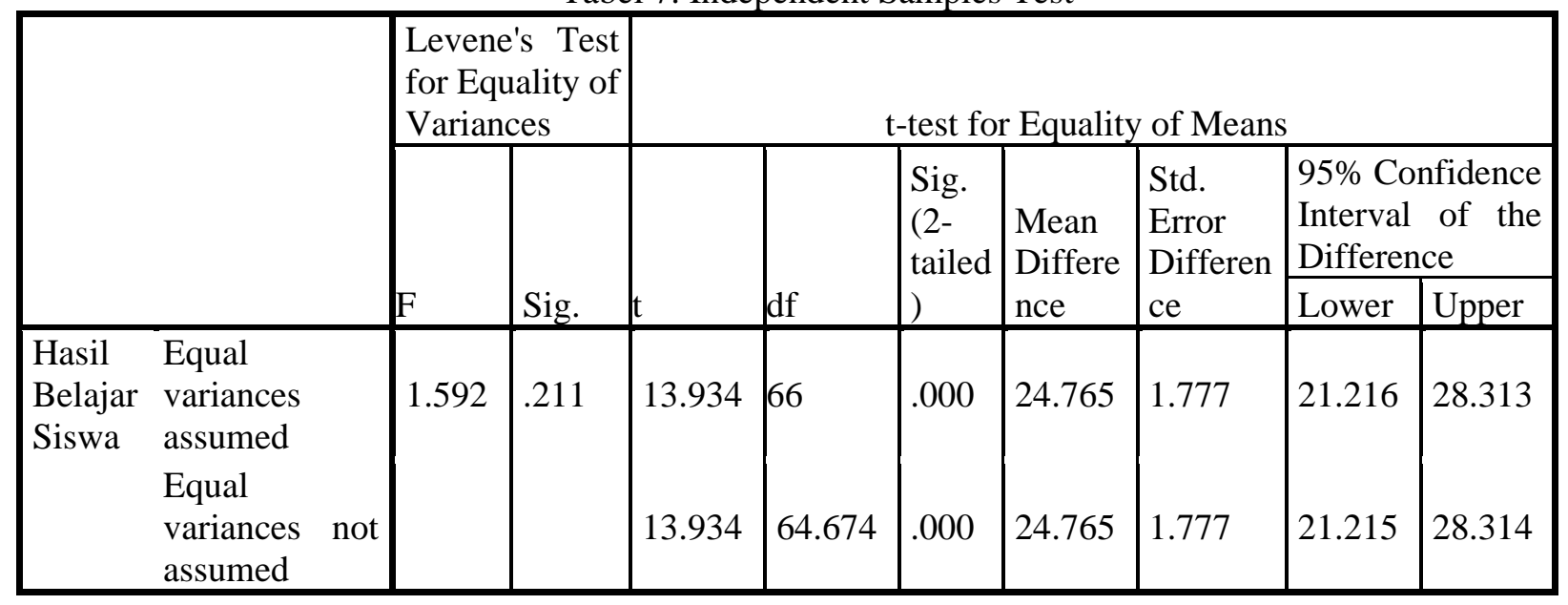

Tabel 8. Group Statistics

\begin{tabular}{|c|c|c|c|c|c|}
\hline & Kelas & $\mathrm{N}$ & Mean & Std. Deviation & $\begin{array}{l}\text { Std.Error } \\
\text { Mean }\end{array}$ \\
\hline Hasil Belajar Siswa & Post-Test Eksperimen & 34 & 90.41 & 6.783 & 1.163 \\
& Post-Test Kontrol & 34 & 65.65 & 7.835 & 1.344 \\
\hline
\end{tabular}


Berdasarkan hasil analisis tersebut diketahui nilai Sig.(2-tailed) $0.000<0.05$ (Ramadhani, 2017) maka dapat disimpulkan bahwa Blended Learning berpengaruh positif dan signifikan terhadap literasi matematika siswa.

\section{Analisis Data Observasi}

Berdasarkan hasil observasi yang dilakukan oleh penulis terhadap karakter belajar siswa, penulis menyimpulkan bahwa sebelum adanya penerapan metode Blended learning keaktifan siswa dalam belajar masih tergolong rendah, setelah penerapan Blended learning siswa lebih aktif dikarenakan adanya penggunaan media yang lebih interaktif seperti pembelajaran secara online.

Pemahaman siswa terhadap matematika sebelum adanya penerapan metode Blended learning masih rendah dikarenakan matematika merupakan salah satu mata pelajaran dengan tingkat kesulitan yang tinggi, akan tetapi setelah adanya penerapan metode Blended learning tingkat pemahaman siswa mengalami peningkatan.

Berdasarkan hasil observasi, cara belajar siswa setelah adanya penerapan metode Blended learning lebih baik dan lebih mandiri dikarenakan akses terhadap maeri belajar lebih mudah dan dapat diakses kapanpun dalam artian selain jam belajar siswa dapat berkomunikasi kepada guru secara daring.

\section{KESIMPULAN}

Berdasarkan hasil penelitian dan pengolahan data yang telah dibahas dapat disimpulkan bahawa penerapan metode pembelajaran Blended learning memiliki dampak terhadap kualitas belajar siswa ditinjau dari literasi matematika pada masa pandemik virus korona. Selain itu diketahui bahwa besar pengaruh metode Blended learning terhadap literasi matematika siswa sebesar 30\%, sedangkan metode belajar konvensional hanya berpengaruh sebesar $2.44 \%$ serta dapat disimpulkan ada perbedaan hasil belajar siswa terhadap metode belajar Blended Learning dan konvensional dengan perbedaan sebesar $24.76 \%$.

\section{UCAPAN TERIMA KASIH}

Terima kasih penulis ucapkan kepada Bapak/Ibu Kepala Sekolah dan Madrasah Aliyah Swasta Pondok Pesantren Irsyadul Islamiyah Tanjung Medan yang sudah bersedia memberikan izin, dan membantu penulis dalam menyelesaikan penelitian ini. Terimakasih kepada Bapak/Ibu dosen yang sudah memberikan arahan selama ini sehingga dapat menyelesaikan publikasi ini.

\section{REFERENSI}

Alan, U. F., \& Afriansyah, E. A. (2017). Kemampuan Pemahaman Matematis Siswa Melalui Model Pembelajaran Auditory Intellectualy Repetition Dan Problem Based Learning. Jurnal Pendidikan Matematika, 11(1). https://doi.org/10.22342/jpm.11.1.3890.67-78

Ariskasari, D., \& Pratiwi, D. D. (2019). Pengembangan Modul Matematika Berbasis Problem Solving pada Materi Vektor. Desimal: Jurnal Matematika, 2(3), 249-258. 
https://doi.org/10.24042/djm.v2i3.4454

Farisi, A., Hamid, A., \& Melvina. (2017). Pengaruh Model Pembelajaran Problem Based Learning terhadap Kemampuan Berpikir Kritis dalam Meningkatkan Hasil Belajar Ssiswa pada Konsep Suhu dan Kalor. Jurnal Ilmiah Mahasiswa, 2(3), 283-287.

Hairi, P. J. (2020). Implikasi Hukum Pembatasan Sosial Berskala Besar Terkait Pencegahan COVID19. Info Singkat Bidang Hukum, 12(April), 1-6. http://berkas.dpr.go.id/puslit/files/info_singkat/Info Singkat-XII-7-I-P3DI-April-2020$\% 0 \mathrm{~A} 240 . \mathrm{pdf} \% 0 \mathrm{~A}$

Hidayat, M. T., Junaidi, T., \& Yakob, M. (2020). Pengembangan Model Pembelajaran Blended Learning dalam Meningkatkan Pemahaman Siswa Terhadap Tradisi Lisan Aceh. 25(3), 401-410.

Indrawati, F. (2020). Peningkatan Kemampuan Literasi Matematika Di Era Revolusi Industri 4.0. Prosiding Seminar Nasional Sains, 1(1), 382-386.

Irfanudin, A. M., Kurniawati, E., Jamaluddin, J., \& ... (2020). Strategi Berbisnis Online Ditengah Pandemi Corona Virus Disease 2019 Covid-19. Dedikasi .., 1(1), 63-68. http://openjournal.unpam.ac.id/index.php/DKP/article/view/6394

Isnawati, I., Jalinus, N., \& Risfendra, R. (2020). Analisis Kemampuan Pedagogi Guru SMK yang sedang Mengambil Pendidikan Profesi Guru dengan Metode Deskriptif Kuantitatif dan Metode Kualitatif. INVOTEK: Jurnal Inovasi Vokasional Dan Teknologi, 20(1), 37-44. https://doi.org/10.24036/invotek.v20i1.652

Nahdi, D. S. (2018). Eksperimentasi Model Problem Based Learning Dan Model Guided Discovery Learning Terhadap Kemampuan Pemecahan Masalah Matematis Ditinjau Dari Self Efficacy Siswa. Jurnal Cakrawala Pendas, 4(1). https://doi.org/10.31949/jcp.v4i1.711

Ningsih, Y. L., Misdalina, M., \& Marhamah, M. (2017). Peningkatan Hasil Belajar dan Kemandirian Belajar Metode Statistika Melalui Pembelajaran Blended Learning. Al-Jabar : Jurnal Pendidikan Matematika, 8(2), 155. https://doi.org/10.24042/ajpm.v8i2.1633

Pamungkas, A., Subali, B., \& Linuwih, S. (2017). Implementasi model pembelajaran IPA berbasis kearifan lokal untuk meningkatkan kreativitas dan hasil belajar siswa. Jurnal Inovasi Pendidikan IPA, 3(2), 118. https://doi.org/10.21831/jipi.v3i2.14562

Ramadhani, H. S. (2017). Hetti Sari Ramadhani. Persona: Jurnal Psikologi Indonesia, 6(2), 66-74.

Ratnawati, E. (2016). Karakteristik Teori-Teori Belajar Dalam Proses Pendidikan (Perkembangan Psikologis Dan Aplikasi). Edueksos: Jurnal Pendidikan Sosial \& Ekonomi, 4(2), 1-23.

Rizkiyah, A. (2013). Penerapan Blended Learning untuk Meningkatkan Hasil Belajar Siswa pada Mata Pelajaran Ilmu Bangunan di Kelas X TGB SMK Negeri 7 Surabaya. Jurnal Kajian Pendidikan Teknik Bangunan, 1(1), 40-49.

Saleh, A. R., Sumarni, E., \& Safitri, S. R. (2014). K Ajian a Nalisis K Epuasan P Elanggan. Jurnal Pustakawan Indonesia, 13(2), 15-27.

Sharma, G. (2017). Pros and cons of different sampling techniques. International Journal of Applied 
Research, 3(7), 749-752. www.allresearchjournal.com

Siliwangi, D. I. I., \& Penelitian, U. (2020). Tahun 2020 Penerapan Blended Learning Dalam Mata Kuliah Umum Bahasa Indonesia.

Sultoni, Gunawan, I., \& Pratiwi, F. D. (2018). Perbedaan Motivasi Belajar Mahasiswa Antara Sebelum. Ilmu Pendidikan: Jurnal Kajian Teori Dan Praktik Kependidikan, 3(1), 115-118.

sutisna, icam. (2020). Statistika penelitian. Universitas Negeri Gorontalo, 1(1), 1-15.

Suyana, N., Ati, A. P., \& Widiyarto, S. (2019). Metode Partisipatori untuk Meningkatkan Kemampuan Menulis Argumentasi Pada Siswa MTs Nurul Hikmah Kota Bekasi. Linguista: Jurnal Ilmiah Bahasa, Sastra, Dan Pembelajarannya, 2(2), 80. https://doi.org/10.25273/linguista.v2i2.3702

Taunu, E. S. H., \& Iriani, A. (2019). Evaluasi Program Penguatan Pendidikan Karakter Terintegrasi Mata Pelajaran Matematika di SMP Negeri. Kelola: Jurnal Manajemen Pendidikan, 6(1), 64-73. https://doi.org/10.24246/j.jk.2019.v6.i1.p64-73

Wahyuni, R. (2019). Kemandirian Belajar Mahasiswa Melalui Blended. Jurnal Ilmiah Pendidikan Matematika AL-QALASADI, 3(2), 76-81.

Wibowo, T. (2019). Pembelajaran Matematika dan Risetnya di Era Revolusi Industri 4.0. Prosiding Sendika, 5(1), 676-686.

Wiliawanto, W., Bernard, M., Akbar, P., \& Sugandi, A. I. (2019). Penerapan Strategi Pembelajaran Aktif Question Student Have Untuk Meningkatkan Kemampuan Berpikir Kritis Matematik Siswa SMK. Jurnal Cendekia: Jurnal Pendidikan Matematika, 3(1), 139-148. https://doi.org/10.31004/cendekia.v3i1.86

Wulandari, A., Rahman, F., Pujianti, N., Sari, A. R., Laily, N., Anggraini, L., Muddin, F. I., Ridwan, A. M., Anhar, V. Y., Azmiyannoor, M., \& Prasetio, D. B. (2020). Hubungan Karakteristik Individu dengan Pengetahuan tentang Pencegahan Coronavirus Disease 2019 pada Masyarakat di Kalimantan Selatan. Jurnal Kesehatan Masyarakat Indonesia, 15(1), 42. https://doi.org/10.26714/jkmi.15.1.2020.42-46. 